\section{East German Academy}

SIR - Nature has given considerable space to discussions of the problems of integration of East German (GDR) scientists and institutions. Every sensible scientist will agree that this integrated German science system should be based on the existing research and research-funding system of the Federal Republic (FRG), but it is strange that Nature's correspondent and the author of a recent leading article (Nature 345, 371-372; 1990) refer to the Academy of Sciences of the GDR as if it were a community comparable, in its composition and procedures, to the academies and research organizations of the West. Particularly strange is Nature's advice that West German scientists, specifically at the Max-Planck-Gesellschaft, should have "of course, to accept that the East Germany Academy of Sciences should be a titularly equal partner".

This view of the GDR Academy, however, is shockingly naive, and overlooks some of the ugly facts of life of science in East Germany. Among the members of the grossly overstaffed GDR Academy and the universities one finds, besides many excellent scientists, a fair number who have reached their privileged and tenured positions not because of outstanding scientific achievements but because they were selected and promoted for political reasons, perhaps because they came from families of the Communist party nobility.

A more serious problem is that it has not yet been possible to identify the many East Germany scientists who have served as an internal Secret Service Cadre ("Sicherheitskader") directed by, and reporting to, the GDR version of the Securitate, the Staatssicherheitsdienst ("Stasi"), spying on their colleagues and on Western visitors. These people were eager to report information indicative of a forthcoming defection of a colleague, and unofficial contacts with Western scientists and non-scientists ("Westkontakte"). As in several other Eastern bloc countries, many of the privileged travel cadre ("Reisekader") returning from visits or congresses to the West would report information that they or the Stasi found interesting, including details of the private lives of their Western colleagues.

GDR scientists also helped the Stasi to identify Western scientists attending research conferences or visiting research laboratories in the DDR who were then placed under observation, with bugged hotel rooms, video cameras and the like. At a dinner during a cell biology meeting near Weimar some years ago, a colleague from a GDR university told me that the same afternoon the Sicherheitskader of this meeting, with prominent colleagues of the academy, had decided that I was to be on the list of those to be secretly observed and, he continued with grim humour, I should take it as an honour.

Academy members were also among the strongest supporters and executors of the suppressive and inhuman science politics of the Party, SED (now shrunk, outwardly metamorphosed and re-named PDS), which excluded for political reasons many gifted and dedicated high school pupils, university students and young scientists from research careers and from international communication. Moreover, some members of the academy were among that most anxious to boycott certain congresses in the West and to vote against GDR membership of international federations, even when most other Socialist countries had already become members (as in the case of the European Cell Biology Organization).

GDR scientists and physicians have also approved or even contributed to secret and inhuman medical manipulations of human beings. These ranged from the spiriting away of some 'difficult' and unwanted people to psychiatric 'sanatoria' to systematic doping of a whole generation of male and female athletes with neuropeptides and androgenic steroids (in some cases enforced with pressure from the Stasi) at a secret government research institute near Kreischa in Saxony, a crime against medical ethics now openly admitted by the new sports leaders of the GDR and some of the professors involved.

Since the 'change' in November 1989, only a few of the academy members responsible for these political actions have been removed from office (not from membership), and the influence of the "old boy network' is still felt - the intellectual chameleons have simply adapted from the old to the new. It is nice of Nature to be so concerned about the future continuing support of the old science establishment of the GDR, notably the academy, but who cares about its victims? I hear the chorus calling "money", but who has heard the sentence "I am sorry"? Who has heard a word of apology to those students, scientists and physicians who suffered during the decades of the SED regime? Where are the signs of a will towards reparations and atonement, the invitations of the 'forgotten generation' of nonconformist scientists to come to the academy laboratories for a fair second chance?

Unfortunately, recent action in GDR research institutes and hospitals suggests that the leading scientists and physicians have not changed but only dissembled. Members were invited to 'retouch' and rephrase their CVs and personal files in the light of the prevailing tone, and doctoral theses with comprising contents 'dis- appeared'. This nationwide faking and covering up, however, shows only that the old spirit of opportunistic lies is still there, and to quote Berthold Brecht: "Der Schoss ist fruchtbar noch, aus dem das kroch" " The womb from which it crawled is still fertile.").

\section{Institut für Zell-und Tumorbiologie. Deutsches Krebsforschungszentrum, D-6900 Heidelberg 1, FRG}

\section{Tomorrow's world}

SIR-Christopher J. Lote (Nature 346; 10; 1990) suggests that just about all scientists are atheists and that this hypothesis should be proved and published. $\mathrm{He}$ seems to think this would result in popular rejection of religion rather than rejection of science.

More seriously, he seems to think nearunanimity among scientists in being atheists supports the notion of atheism. Alas, humans have a habit of believing in what they are doing. I am a physician, and my discipline takes as an assumption that "the human body is there to be tampered with". I may have a difference of opinion with most my fellows as to when life "really" begins and "really" ends. A palace guard who took the job just because it was a meal ticket may in time be loyal to the king.

When science was called "natural philosophy", the great Western religions, Christianity and Islam, took as an assumption the impending fundamental alteration of the Universe. Even Teutonic paganism conceded a twilight of the gods. Greek paganism, which accepted a beginning but no impending end of the Universe, had fallen out of favour. Natural philosophy took as an assumption, "What if what you see is what you get? What if tomorrow is going to be about like today?" The answer, elegantly recorded in your publication, does not go one step toward proving that tomorrow will be like today. Nor does the general agreement of those who work under the assumption support it. Lote should know this.

Actually there is a little theorem in general relativity, the smell of which I feel sure led to Einstein's "blunder", that would predict an unstable Universe and an after-death hell quite horrible enough for any Calvinist. I cannot prove the theorem. (Physicians don't often do that kind of work.) But I can describe it for you. And based on it, I can give a cosmology that can at least be disproved by the proper astronomical measurements.

Certainly religions vary. But many of them are attempts by this tribe or that to come to grips with the question, "What if tomorrow is different?"

M. L. HERBERT

216 Harbor View Lane,

Largo, Florida 34640, USA 